\title{
Cultural Resource Assessment of the Test Area North Demolition Landfill at the Idaho National Engineering and Environmental Laboratory
}

B. R. Pace

July 2003

Idaho National Engineering and Environmental Laboratory Bechtel BWXT Idaho, LLC 
INEEL/EXT-03-00869

\title{
Cultural Resource Assessment of the Test Area North Demolition Landfill at the Idaho National Engineering and Environmental Laboratory
}

\author{
B. R. Pace \\ July 2003 \\ Idaho National Engineering and Environmental Laboratory \\ Idaho Completion Project \\ Idaho Falls, Idaho 83415
}

Prepared for the

U.S. Department of Energy

Assistant Secretary for Environmental Management

Under DOE Idaho Operations Office

Contract DE-AC07-99ID13727 


\begin{abstract}
The proposed new demolition landfill at Test Area North on the Idaho National Engineering and Environmental Laboratory (INEEL) will support ongoing demolition and decontamination within the facilities on the north end of the INEEL. In June of 2003, the INEEL Cultural Resource Management Office conducted archival searches, field surveys, and coordination with the ShoshoneBannock Tribes to identify all cultural resources that might be adversely affected by the project and to provide recommendations to protect those listed or eligible for listing on the National Register of Historic Places. These investigations showed that landfill construction and operation would affect two significant cultural resources. This report outlines protective measures to ensure that these effects are not adverse.
\end{abstract}




\section{CONTENTS}

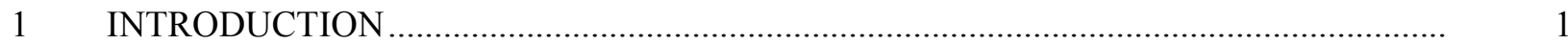

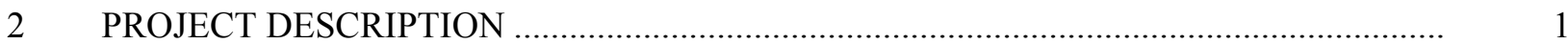

2.1 Description of Project and Potential Impacts ...........................................................

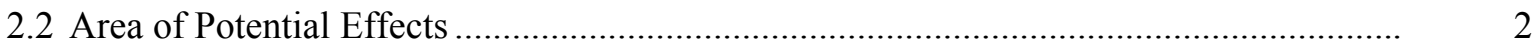

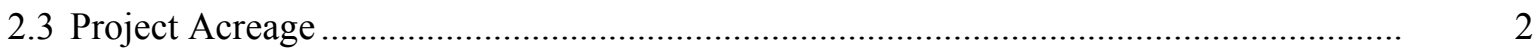

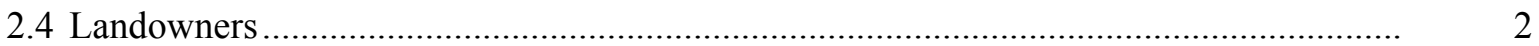

3 STATEMENT OF OBJECTIVES FOR INVESTIGATION ……...................................... 2

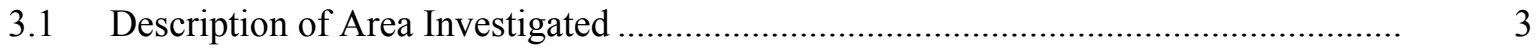

3.2 Amount and Types of Information Collected …....................................................

$4 \quad$ LOCATION AND GENERAL ENVIRONMENTAL SETTING ....................................... 3

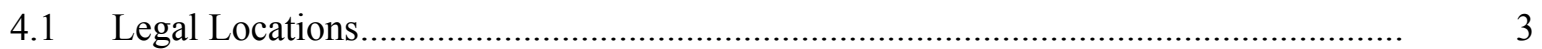

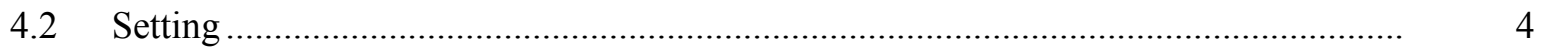

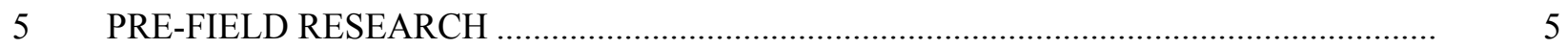

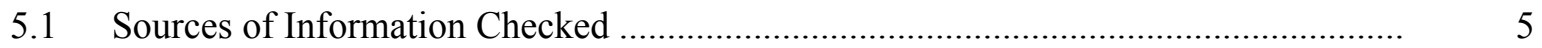

5.2 Summary of Previous Investigations ...................................................................... 5

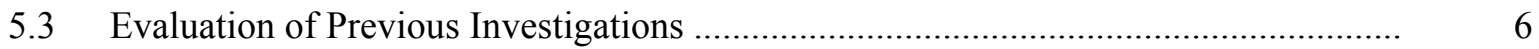

6 EXPECTED HISTORIC AND PREHISTORIC LAND USE AND SITE DENSITY ........... 6

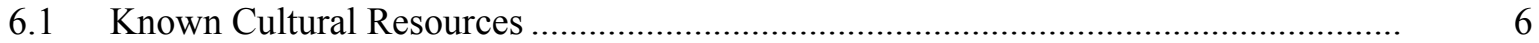

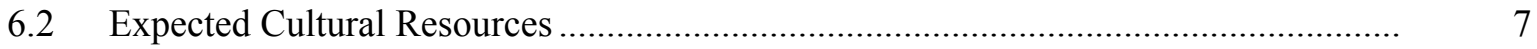

6.3 Known or Expected Distribution of Cultural Resources ............................................

6.4 Known or Expected General Themes and Time Periods .........................................

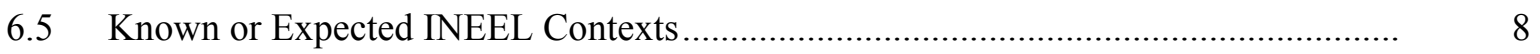

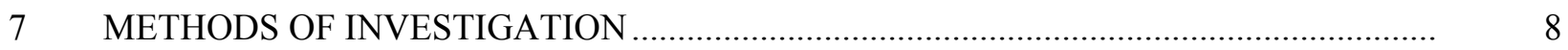

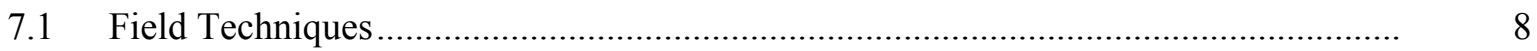




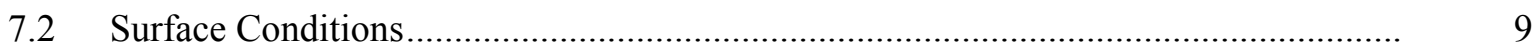

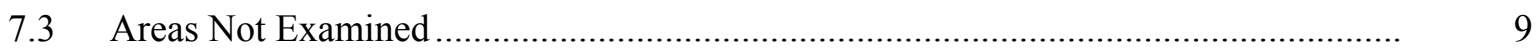

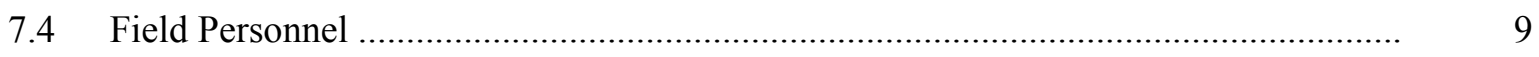

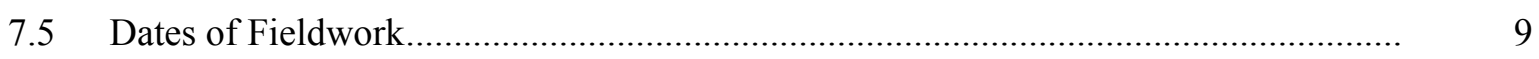

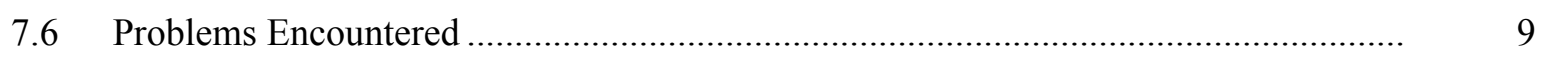

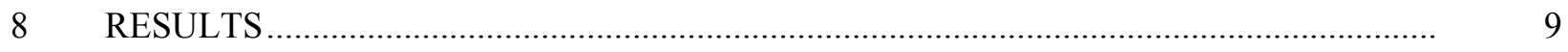

8.1 All Cultural Resources Identified in the Area of Potential Effects ............................ 9

8.2 Cultural Resources Noted But Not Recorded ................................................... 10

8.3 Summary of Important Characteristics of Identified Resources ................................ 11

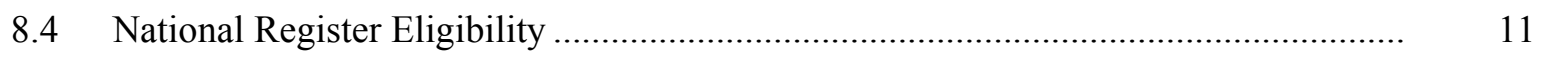

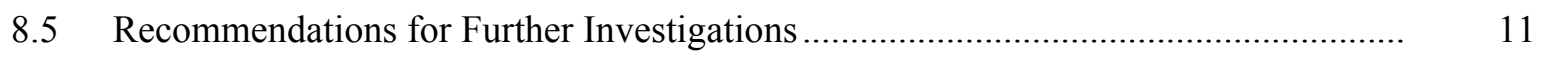

9 CONCLUSIONS AND RECOMMENDATIONS ….................................................... 12

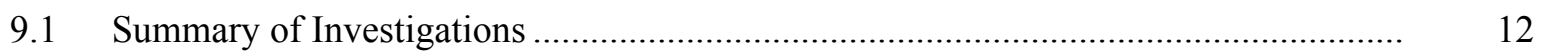

9.2 Potential Threats to Identified Cultural Properties ................................................ 12

9.3 Relationship of Identified Cultural Properties to Project Impacts ............................. 12

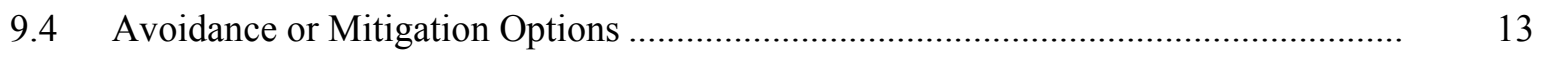

9.5 Recommendations for Additional Investigations or Protection Measures................... 13

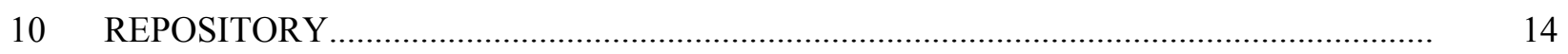

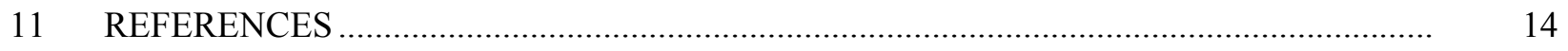

APPENDIX A: Key Information

APPENDIX B: Certification of Results

APPENDIX C: Project Maps

APPENDIX D: INEEL Site Recording Forms 


\section{Cultural Resource Assessment of the Test Area North Demolition Landfill at the Idaho National Engineering and Environmental Laboratory}

\section{INTRODUCTION}

The following report documents archive searches, field investigations, and tribal coordination to identify cultural resources that might be impacted by activities associated with the construction and operation of a new landfill at Test Area North (TAN) on the Idaho National Engineering and Environmental Laboratory (INEEL). The report follows a specific format preferred by the Idaho State Historic Preservation Office (SHPO) (Idaho SHPO 1995).

\section{PROJECT DESCRIPTION}

The proposed project includes development and operation of a new solid waste landfill at TAN on the north end of the INEEL.

\subsection{Description of Project and Potential Impacts}

The INEEL is an 890 square mile federal reserve covering portions of five counties on the northeastern edge of the Snake River Plain in southeastern Idaho. The lands included within the boundaries of the INEEL are under the jurisdiction of the U.S. Department of Energy, Idaho Operations Office (DOE-ID) and have been set aside since the 1940s to support many kinds of scientific and engineering research. The vast land holding has also been designated as a National Environmental Research Park, dedicated to the study of the environmental impacts of energy research. Recently, approximately 74,000 acres of high desert terrain within the Laboratory were designated as an INEEL Sagebrush Steppe Ecosystem Reserve, recognizing the undisturbed nature of the area and the many resources present within.

There are currently eleven main operational facility areas at the INEEL (Map 1, Appendix C). The northernmost of these, designated as TAN, is the nearest facility to the new landfill. The purpose of the new landfill will be to accept solid waste (i.e. concrete, untreated wood scrap, metal siding, etc.) generated during decontamination and decommissioning (D\&D) of buildings and structures at nearby facilities. Impacts to historic properties in the built environment as a result of this D\&D effort are addressed in a separate study (Braun 2002). The landfill portion of the D\&D effort will affect no buildings or structures. Significant cost savings will be accrued through development and use of this new landfill as compared to use of an existing solid waste landfill at INEEL's Central Facilities Area, 30 miles to the southwest.

The proposed new demolition landfill is located in the northern portion of the INEEL between TAN's Technical Support Facility (TSF) and the now demolished Initial Engine Test Facility (IET) (Map 2, Appendix C). Plans for development of this 64-acre area call for eventual construction of individual landfill cells along the base of and oriented parallel to the steep embankment that runs roughly northsouth between these two facilities. On the northern end of the proposed landfill, the embankment marks the old shoreline of Pleistocene Lake Terreton where it remains largely undisturbed save for natural erosion and a buried waterline that runs along the top of the embankment between the facilities. Near the TSF perimeter fence however, the shoreline has been modified to fit facility-specific landscaping needs.

Landfill operations will take advantage of the overburden contained within the embankment. Solid waste will be taken to a prepared area at the base of the embankment and overburden present in the embankment 
will be loosened and then pushed over the top for cover. Preparations at the base of the embankment will include limited squaring off and compaction. Development of the landfill will begin near the center of the 64-acre area and proceed in a northerly direction as overburden materials are exhausted. The next cell slated for development will be located immediately to the north of the first and so on. The 64-acre landfill site is expected to be more than adequate to accommodate approximately $250,000 \mathrm{~m}^{3}(327,000$ $\mathrm{yd}^{3}$ ) of solid demolition debris likely to be generated over the life of the landfill.

In June of 2003, archive searches, intensive field surveys, and tribal interactions were conducted to determine if the ground disturbance and development associated with the new landfill will cause any impacts to cultural resources, particularly those listed on or potentially eligible for listing on the National Register of Historic Places (NRHP). The methods used and the results of these efforts are summarized in the sections to follow.

\subsection{Area of Potential Effects}

The area of potential effects for construction and operation of the demolition landfill at TAN includes the 64-acre landfill site as well as approximately 0.5 mile of access road (Map 2, Appendix C). Ground disturbance within the 64-acre landfill area will be intensive and involve the use of heavy equipment to reshape the embankment for use as overburden and ultimately to provide a permanent cover for the uncontaminated solid demolition waste. An existing road will be utilized for access to the 64-acre landfill and only one segment, currently an unimproved gravel/dirt road, will require modification.

\subsection{Project Acreage}

\begin{tabular}{|l|l|l|}
\hline NAME OF AREA & PROJECT ACREAGE & ARCHAEOLOGICAL SURVEY STATUS \\
\hline Landfill & 64 acres & $\begin{array}{l}\text { Narrow zone along TAN-TSF fence and in general } \\
\text { vicinity of IET previously surveyed (Reed et al. } \\
1987) ; \text { remainder unsurveyed. }\end{array}$ \\
\hline Access Road & $\begin{array}{l}1.75 \text { acres (0.5 mile long, } \\
20 \text { meters wide) }\end{array}$ & Established road unsurveyed \\
\hline
\end{tabular}

\subsection{Landowner(s)}

The U.S. Department of Energy, Idaho Operations Office (DOE-ID) and DOE-ID's prime contractor, Bechtel BWXT, Idaho, LLC, jointly administer most INEEL lands, excluding those that are within the Naval Reactors Facility and Argonne National Laboratory-West. Within the INEEL grazing area, administration is also shared with the Bureau of Land Management, Idaho Falls District, who issues all permits and takes responsibility for grazing activities. Lands included within the proposed TAN Demolition Landfill are under the sole jurisdiction of DOE-ID.

\section{STATEMENT OF OBJECTIVES FOR INVESTIGATION}

The cultural resource investigations reported herein were conducted to satisfy three basic and interrelated goals:

- identify and evaluate cultural resources within the areas of potential effect for construction and operation of the new demolition landfill at TAN, 
- conduct a preliminary assessment of the potential effects of construction activities on any identified cultural resources, and

- develop preliminary avoidance strategies, monitoring plans and/or data recovery plans if necessary to avoid any adverse effects to identified cultural resources and particularly those that are listed on or eligible for listing on the National Register of Historic Places.

\subsection{Description of Area Investigated}

Intensive archaeological surveys were completed within the entire 64-acre proposed landfill as well as along the 0.5 mile road that will be upgraded to provide access.

\subsection{Amount and Types of Information Collected}

All cultural resources investigations on the INEEL must meet the Secretary of the Interior's standards under 36 CFR 800, as well as the requirements outlined in the draft INEEL Cultural Resources Management Plan (DOE/ID 2000). Ground disturbing projects on the INEEL are preceded by several types of data collection including: cultural resource archive searches, archaeological reconnaissance surveys in previously examined areas, and/or intensive archaeological surveys in areas that have never been systematically inventoried for cultural resources. Representatives from the Shoshone-Bannock Tribes are involved in all field surveys and are consulted in the identification of resources of traditional cultural or religious importance. All of these activities are designed to identify cultural resources in the area(s) of potential effect for the proposed activities.

Archive searches completed for the TAN Landfill project showed that only a small portion of the proposed landfill located along the TAN-TSF perimeter fence and in the vicinity of IET had been previously inventoried for cultural resources. However, since these earlier inventories were completed more than a decade ago, the entire area of proposed development for the landfill was intensively surveyed or resurveyed in June 2003.

\section{LOCATION AND GENERAL ENVIRONMENTAL SETTING}

The proposed landfill at TAN is located in the northern portion of the INEEL in Butte County near the Jefferson County Line approximately 11.5 miles west of the small community of Mud Lake, ID.

\subsection{Legal Locations}

Specifically, the landfill occupies the central portion of the southern half of Section 12 and central portion of the northern half of Section 13, T6N, R31E. A number of maps are included in Appendix C to provide additional detail on the project including:

- a map showing the location of INEEL boundaries and major facilities (Map 1)

- a partial 7.5' topographic map (Circular Butte, Idaho) showing the area of potential effects for the proposed landfill and associated access road (Map 2)

- a partial 7.5' map (Circular Butte, Idaho) showing cultural resources within or near the area of potential effects for the proposed landfill (Map 3)

- a plot plan of the proposed landfill illustrating the location of significant cultural resources in relation to operational features (Map 4) 


\subsection{Setting}

The INEEL is located in the high cool desert environment of the northeastern Snake River Plain. Within the 890 square mile laboratory complex, aeolian, alluvial, and lacustrine sediments of varying thickness' overlie basaltic lava flows. The Big Lost River flows in a northeasterly direction from the southwestern corner of the Laboratory to eventually terminate in a series of natural sinks near the foothills of the Lemhi Mountains. An extensive floodplain follows the course of the River and in the vicinity of the sinks, a myriad of channels is cut into the now-dry bed of Pleistocene Lake Terreton. Vegetation is generally sparse throughout the INEEL and dominated by a community of low shrubs like sage and rabbitbrush, a wide variety of grasses and forbs, and occasional juniper trees. Many animals make their homes in this sagebrush grassland including pronghorn, deer, elk, coyotes, badgers, rabbits, many birds including raptors, game birds, and waterfowl, a wide variety of small rodents, and several types of small reptile.

For human populations, the area has always had much to offer. For Native American hunter-gatherers who probably utilized the area on a seasonal basis for more than 12,000 years, game animals and useful plants were found in abundance and nearby Big Southern Butte was attractive for the obsidian toolstone that outcrops near it's crest. Within the last 150 years, emigrants began to pass through the area along a northern spur of the Oregon Trail (Goodale's Cutoff). Soon thereafter, early homesteaders sought to harness the fickle flows of the Big Lost River and transform sagebrush flats into green pastures. Few were successful, but the failure of their efforts opened the area for use of another kind. The remote and largely uninhabited expanse of the northeastern Snake River Plain was well suited for the test firing of large guns and ordnance testing in support of US military applications. After this initial period of military use, the INEEL was designated as the National Reactor Testing Station and became an ideal testing ground for the developing U.S. nuclear research program after 1949. The Laboratory has filled a similar role for more than 50 years, ultimately influencing nearly every power reactor in the world particularly in regard to design and safety.

Much of the northern portion of the INEEL where the proposed TAN demolition landfill is located is contained within the basin of Pleistocene Lake Terreton. This wide, shallow body of water probably reached maximum extent at approximately $4800 \mathrm{ft}$ elevation at several times during the Pleistocene and began to recede at the close of the last glacial period approximately 11,000 years ago (Nace et al. 1975, Gianniny et al. 2002). However, palynological evidence suggests that the basin may have also filled as recently as 700 years BP (Bright and Davis 1982, Gianniny et al. 2002). Presently, the basin of Lake Terreton is dry throughout the year. However in the Spring, the Big Lost River Sinks, modern remnants of the Lake, can fill with water.

Terrain within the Terreton Basin is generally flat and featureless. Very fine lacustrine silts and clays make up the dominant soil cover but in many areas these soils are overlain by longitudinal Holocene sand dunes deposited by the prevailing southwesterly winds. Old shorelines, bars, and spits also provide some local topographic variation such as that seen within the proposed landfill site. Vegetation in the basin reflects the depth and complexity of local soils. Thus, various grasses, annual mustard, and some rabbitbrush dominate the Holocene dunes, while the more alkaline lacustrine deposits contain brushy species (saltbrush, sagebrush, rabbitbrush) and some grasses. Local variation is quite high throughout the entire area. Animal visitors include a large number and variety of migratory waterfowl, some big game animals such as antelope and elk, and several small mammals, rodents, and birds that maintain full-time residence.

Test Area North is constructed on the shoreline of Pleistocene Lake Terreton (4800 ft elevation) near the Birch Creek Sinks. Within the fenced perimeter of TAN/TSF, construction activities have changed the character of any natural features. Ground disturbance adjacent to but outside the TAN/TSF fence in the area of the first landfill cells to be opened has also been quite intensive. Road construction, subsurface utilities, modification to the Lake Terreton shoreline, railroad construction, and large scale surface 
dumping are a few of the impacting agents. The setting that remains is dominated by weedy plant species (cheatgrass, mustard, halogeton) and is subject to some light but large-scale sheet erosion.

In general, the Lake Terreton environment would have provided many attractions to prehistoric huntergatherers. The marshy wetlands would have provided a variety of useful plants (i.e. cattails), foodstuffs (i.e. freshwater shrimp, migratory waterfowl, big game animals), and of course, water, on a predictable seasonal basis.

\section{PRE-FIELD RESEARCH}

The INEEL Cultural Resource Management (CRM) Office maintains records of all cultural resource investigations conducted on the INEEL. This includes a wide variety of supporting documentation as well as the following specific records:

- reconnaissance-level archaeological surveys completed before 1984

- intensive archaeological surveys completed after 1984

- archaeological sensitivity maps with predicted resource densities (Ringe 1995, Holmer et al. 2002)

- maps and survey notes from original government-sponsored land surveys of the INEEL area

- records of formal architectural surveys of all DOE-ID owned INEEL buildings (Arrowrock 1997)

- historic and current plot plans of INEEL buildings and facility areas

- databases with information specific to the archaeological sites and historic architectural properties that have been evaluated as eligible for listing on the National Register of Historic Places

All archaeological investigations on the INEEL are preceded by archival checks to determine the nature and extent of previous research in a given area.

5.1 Sources of Information Checked

\begin{tabular}{|l|l|}
\hline [x] General Overviews & {$[$ ] Ethnographic studies } \\
\hline [ ] National Register & {$[\mathrm{x}]$ Historic records/maps } \\
\hline$[\mathrm{x}]$ Archaeological site records/maps & {$[$ ] Interviews } \\
\hline [ ] Architectural site records/maps & {$[\mathrm{x}]$ INEEL CRM Files } \\
\hline$[\mathrm{x}]$ Survey records & {$[$ ] Other } \\
\hline
\end{tabular}

\subsection{Summary of Previous Investigations}

A check of INEEL CRM archives revealed that two archaeological surveys had been previously completed within the area of potential effects for the proposed TAN Demolition Landfill. The first of these was part of a program to ensure that no significant cultural resources would be adversely impacted by increased security precautions being implemented around the perimeters of major INEEL facilities. During this project in 1985, the Swanson/Crabtree Anthropological Research Laboratory (SCAR-Lab) at Idaho State University (ISU) conducted many intensive archaeological surveys of 100 meter-wide zones surrounding major INEEL facilities. When the TAN facility perimeter was examined, no cultural resources were identified (Reed et al. 1987:257). The extreme southern portion of the TAN Demolition Landfill was examined as part of this early survey. 
Later in 1985, the crew from ISU returned to the TAN area to complete a second archaeological survey of areas within and around the IET facility. Three finds were documented during this survey, all isolated artifacts recommended as ineligible for nomination to the National Register of Historic Places (Reed et al. 1987:260-262). A small portion of the area examined during this early survey is included within the extreme northern portion of the TAN Demolition Landfill and one of the finds, designated as 10-BT1236 , is included within the area of potential effects. A second find designated as 10-BT-1237 is just outside of the proposed new landfill. Both of these localities appear on maps in Appendix C (Map 3).

Several additional surveys (Miller 1984, Ross, Ringe and Reed 1986, Ringe and Reed 1987, Reed et al. 1987, Pace 2000) and a small test excavation (Ringe 1996) have also been completed in the vicinity of the proposed TAN Demolition Landfill. However, all of these previous investigations are peripheral to the area of potential effects for the current project.

\subsection{Evaluation of Previous Investigations}

Archaeological surveys completed prior to 1984 on the INEEL were not necessarily of intensive levels and documentation is inadequate and often nonexistent. It is the policy of the INEEL CRM Office to re-survey these areas whenever they fall within the boundaries of a new ground disturbing projects. It is also the policy of the INEEL CRM Office to conduct reconnaissance examinations of areas that were intensively surveyed more than ten years ago when they happen to fall within the boundaries of a new grounddisturbing project. Both of these policies help to ensure that any area proposed for new ground disturbance is intensively examined (transect interval $\leq 20 \mathrm{~m}$ ) and all cultural resources with visible surface remains are documented. At the proposed TAN Landfill, all areas of possible ground disturbance were intensively surveyed in June of 2003, even those small portions of the project area that had been previously examined.

\section{EXPECTED HISTORIC AND PREHISTORIC LAND USE AND SITE DENSITY}

Previous archaeological investigations in the TAN area provide the basis for estimates of cultural resource density and distribution in the TAN Demolition Landfill project area as presented in the sections to follow.

\subsection{Known Cultural Resources}

Within the inventory of known, previously recorded cultural resources in the vicinity of TAN are short term hunting camps, tool modification localities, and isolated artifacts from the prehistoric period $(12,000$ -150 years ago) as well as turn-of-the-century trash dumps and old stage and wagon roads from the historic period ( $150-50$ years ago). Only two known cultural resources have been identified within or close to the Tan Landfill project area. Both of these resources consisted of isolated prehistoric artifacts and were evaluated by the ISU archaeologists as ineligible for nomination to the National Register (Reed et al. 1987). Additional artifacts discovered at each of these localities during the Landfill surveys in June 2003 force a reconsideration of these initial evaluations. Descriptions are included in the following table:

\begin{tabular}{|l|l|l|l|l|}
\hline Site No. & Project & Site Type & Site Description & $\begin{array}{l}\text { Position Relative to Landfill Area } \\
\text { of Potential Effects }\end{array}$ \\
\hline 10-BT-1236 & $\begin{array}{l}\text { IET surveys } \\
1985\end{array}$ & Isolated Find & $\begin{array}{l}\text { Elko Corner-notched } \\
\text { projectile point fragment } \\
(3,500-1,300 \text { BP) }\end{array}$ & $\begin{array}{l}\text { Inside northern portion of proposed } \\
\text { landfill (Map 3, Appendix C) }\end{array}$ \\
\hline $10-$ BT-1237 & $\begin{array}{l}\text { IET surveys } \\
1985\end{array}$ & Isolated Find & $\begin{array}{l}\text { Bitterroot Side-notched } \\
\text { projectile point fragment } \\
(7,500-5,000 \mathrm{BP})\end{array}$ & $\begin{array}{l}30-50 \text { m outside proposed landfill } \\
\text { (Map 3, Appendix C) }\end{array}$ \\
\hline
\end{tabular}




\subsection{Expected Cultural Resources}

Cultural resources are widespread and numerous across the entire INEEL. Given the results of previous surveys in the vicinity of TAN, additional archaeological sites and isolates were expected to occur in the unsurveyed portions of the proposed landfill. Previous investigations further indicated that these sites would likely be representative of both prehistoric and historic time frames. The prehistoric sites likely to be present might range in age from Early Prehistoric (15,000 - 7,500 BP) through Middle Prehistoric $(7,500-1,300$ BP) and Late Prehistoric (1,300 - 300 BP) and into the Protohistoric Period (300 - 150 $\mathrm{BP})$. Further, it is likely that any new prehistoric sites identified would represent short-term camping activities, hunting and gathering, and stone tool maintenance/ manufacture. A focus on resources associated with Lake Terreton would also be expected for certain time periods.

Historic period sites (150 - 50 BP) have been found to be less common in the TAN area than prehistoric sites and most have been associated with overland travel along old stage and wagon roads from the turn of the century. Similar patterns were expected in the unsurveyed TAN Landfill project area, although the nearest historic trail is more than 1 mile away.

\subsection{Known or Expected Distribution of Cultural Resources}

Again, in unsurveyed areas, archaeological sites were expected to occur in frequencies and distributions similar to those previously observed and briefly described above.

6.4 Known or Expected General Themes and Time Periods

\begin{tabular}{|l|l|l|}
\hline \multicolumn{2}{|c|}{ THEMES } & TIME PERIODS \\
\hline [x] Archaeology & [ ] Military & [x] Prehistoric \\
\hline [x] Agriculture & [ ] Mining & [x] Historic Native American \\
\hline [ ] Architecture & [x] Native Americans & [x] Exploration: 1805-1860 \\
\hline [ ] Civilian Conservation Corps & [ ] Politics/Government. & [x] Settlement: 1855-1890 \\
\hline [x] Commerce & [ ] Public Land Management & [x] Statehood: 1890-1904 \\
\hline [ ] Communication & [ ] Recreation/Tourism & [x] Statehood: 1904-1920 \\
\hline [ ] Culture and Society & [x] Settlement & [x] Interwar: 1920-1940 \\
\hline [ ] Ethnic heritage & [ ] Timber & [x] Pre-Modern: 1940-1958 \\
\hline [ ] Exploration/Fur Trade & [x] Transportation & [ ] Modern: 1958-present \\
\hline [ ] Industry & [ ] Other & \\
\hline
\end{tabular}




\subsection{Known or Expected INEEL Contexts}

\begin{tabular}{|l|l|l|}
\hline $\begin{array}{l}{[\mathrm{x}] \text { Prehistoric Native American: }} \\
15,000-150 \mathrm{BP} .\end{array}$ & $\begin{array}{l}\text { [ ] Ordnance Testing, Naval } \\
\text { Proving Ground: } 1942-1949\end{array}$ & $\begin{array}{l}{[\mathrm{x}] \text { Nuclear Reactor Testing, }} \\
\text { Development: } 1955-1970\end{array}$ \\
\hline $\begin{array}{l}\text { [x] Historic Native American: 150 } \\
\text { BP - present }\end{array}$ & [ ] Ordnance Testing, Vietnam \\
War: $1968-1970$ & $\begin{array}{l}\text { [x] Post Nuclear Reactor Research: } \\
1971-\text { present }\end{array}$ \\
\hline $\begin{array}{l}\text { [x] Euroamerican Contact/ } \\
\text { Settlement: } 1805-1942\end{array}$ & $\begin{array}{l}\text { [x] Nuclear Reactor Testing, } \\
\text { Establishment: } 1949-1971\end{array}$ & $\begin{array}{l}\text { [ ] Remediation of Nuclear Waste: } \\
1971-\text { present }\end{array}$ \\
\hline
\end{tabular}

\section{METHODS OF INVESTIGATION}

All work during the June 2003 cultural resources investigations for the proposed landfill at TAN was performed in a manner consistent with formal and informal standards and guidelines issued by the Idaho State Historic Preservation Office (SHPO), the Advisory Council on Historic Preservation (ACHP), the National Park Service (NPS), and Department of Interior (DOI), as outlined in DOE-ID's Cultural Resource Management Plan (DOE/ID 2000).

\subsection{Field Techniques}

The field survey tactics employed during the project were designed to provide intensive visual coverage of the current ground surface to ensure that all cultural resources with visible surface remains were identified. This was accomplished through the use of systematic pedestrian transects by 1-3 surveyors walking no more than $20 \mathrm{~m}$ apart in skirmish line fashion. In the 64-acre landfill area, two long northsouth transects along the top of the Lake Terreton shoreline were completed initially and the remainder of the plot was examined in shorter east-west transects between the initial north-south transects on top of the embankment and the railroad tracks. Along the 0.5 mile access road, one transect was examined on either side of the graveled surface. Fieldwork in both areas was facilitated by trouble-free access on existing roadways, excellent ground visibility, and knowledgeable project personnel.

In general, when cultural materials were encountered during an intensive survey transect, careful searches (3-5 meter survey intervals) were conducted to ascertain the boundaries of the resource and to pinpoint temporally or functionally diagnostic artifacts, artifact concentrations, cultural features, and any areas of post-depositional disturbance. When single, isolated, unmodified flakes were identified during this process, notations were made on field maps but no formal site recording forms were prepared.

Occurrences of $2-10$ artifacts or any number of diagnostic artifacts were classified as "isolates" and were formally recorded. Formal recording was also completed for "sites" ( $\geq 10$ items within $100 \mathrm{~m}$ or any number of items within an active geologic setting). Prior to the completion of site recording forms, resources were also classified as "historic" ( $<150$ years old) or "prehistoric" ( $\geq 150$ years old), and marked accordingly on field survey maps. Planimetric maps showing the locations of all diagnostic artifacts, artifact clusters, and cultural features in relation to a centralized datum and also illustrating basic spatial relationships between the cultural materials and local topographic and/or modern features were prepared for all sites. These maps accompany INEEL-tailored site recording forms, which require detailed administrative, environmental, and descriptive information in a standardized format. Isolates were documented on an abbreviated version of the standard form. A no collection policy was observed for all artifacts during the surveys.

Site recording forms completed for the resources identified during the TAN Landfill survey are included with this report as Appendix D and site locations are depicted on maps in Appendix C. However, because specific information on the locations of cultural resources is distributed on a need-to-know basis, this information may have been removed from some versions of the document. 


\subsection{Surface Conditions}

Sparse vegetation on the INEEL provides excellent surface visibility. In the TAN area, patches of barren soil also greatly facilitate visibility. In general, only $10 \%$ of the existing ground surface is obscured by vegetation.

\subsection{Areas Not Examined}

All areas proposed for ground disturbance during the construction and operation of the new landfill at TAN were intensively surveyed as part of this project.

\subsection{Field Personnel}

B. R. Pace of the INEEL Cultural Resource Management Office directly supervised all fieldwork during the project. Assistance was provided by LaRae Buckskin and Gifferd Osborne from the Shoshone-Bannock Tribes, as well as INEEL employees, Rod Remsburg and Gail Heath.

\subsection{Dates of Fieldwork}

All fieldwork was completed in June of 2003.

\subsection{Problems Encountered}

No problems were encountered.

\section{RESULTS}

Intensive archaeological surveys conducted for the proposed TAN Landfill project in June of 2003 resulted in the documentation of two significant archaeological sites, one isolated find, and ten widely scattered nondiagnostic flakes within the area of potential effects for construction and operation. The majority of these materials had never been documented before. However, one archaeological site in the northern portion of the project area appears to have been originally recorded as an isolated artifact location by archaeologists from ISU in 1985 (2003-22-3/10-BT-1236). Site recording forms with detailed documentation of these resources are provided in Appendix D and the resources are plotted on maps provided in Appendix C (Maps 3 and 4).

\subsection{All Cultural Resources Identified in the Area of Potential Effects}

\begin{tabular}{|l|l|l|l|l|}
\hline Field No. & Site No. & Site Type & Site Description & $\begin{array}{l}\text { Position Relative to } \\
\text { Area of Potential } \\
\text { Effects }\end{array}$ \\
\hline $2003-22-3$ & $10-$ BT-1236 & $\begin{array}{l}\text { Prehistoric Campsite } \\
\text { Middle Prehistoric III } \\
(3,500-1,300) \text { and } \\
\text { Late Prehistoric II } \\
(700-150 \text { BP) }\end{array}$ & $\begin{array}{l}\text { Small scatter of lithic debris and } \\
\text { ceramic sherds originally recorded as } \\
\text { an isolated artifact by ISU (Reed et al. } \\
\text { 1987). Artifacts include flakes, an } \\
\text { Elko Corner-notched point fragment } \\
\text { (found in 1985), an obsidian scraper, } \\
\text { and 35+ sherds from a flat-bottomed } \\
\text { pottery vessel. Artifacts are located in } \\
\text { a low swale adjacent to the embank- } \\
\text { ment marking the margin of Lake } \\
\text { Terreton. }\end{array}$ & $\begin{array}{l}\text { Inside northern } \\
\text { portion of proposed } \\
\text { landfill. Top of } \\
\text { embankment } \\
\text { approximately 25 } \\
\text { meters from the } \\
\text { edge. }\end{array}$ \\
\hline $2003-22-2$ & & Bsolated Find & Basal portion of a Desert Side-notched \\
\hline
\end{tabular}




\begin{tabular}{|l|l|l|l|}
\hline & $\begin{array}{l}\text { Late Prehistoric II } \\
(700-150 \mathrm{BP})\end{array}$ & $\begin{array}{l}\text { point and a white chalcedony } \\
\text { percussion biface, possibly used as a } \\
\text { knife. Artifacts are located on top of } \\
\text { the embankment that marks the edge } \\
\text { of Lake Terreton in this area. }\end{array}$ & $\begin{array}{l}\text { portion of proposed } \\
\text { landfill. Top edge } \\
\text { of embankment. }\end{array}$ \\
\hline $2003-22-1$ & $\begin{array}{l}\text { Middle Prehistoric III } \\
(3,500-1,300)\end{array}$ & $\begin{array}{l}\text { Moderately dense scatter of lithic } \\
\text { debris, projectile points, fire-cracked } \\
\text { rock, burned bone, and processing } \\
\text { tools. Diagnostics include four Elko } \\
\text { Corner-notched point fragments, four } \\
\text { nondiagnostic point fragments, three } \\
\text { scrapers, ground stone, a cannon bone } \\
\text { (large mammal), and several mussel } \\
\text { shell fragments. Artifacts are } \\
\text { concentrated in a 60m x 30m area on } \\
\text { top of the embankment marking the } \\
\text { edge of Lake Terreton and are eroding } \\
\text { down the steep face. Approximately } \\
\text { ten outlying flakes are also scattered } \\
\text { within a 200m zone along the } \\
\text { embankment to the north. }\end{array}$ & $\begin{array}{l}\text { Inside south-central } \\
\text { portion of proposed } \\
\text { dondfill. Top of and } \\
\text { embankment }\end{array}$ \\
\hline
\end{tabular}

\subsection{Cultural Resources Noted but Not Recorded:}

All diagnostic artifacts and concentrations of more than ten artifacts of any kind (archaeological sites) within the area of potential effects for the TAN Landfill project were formally recorded and are described above. Nondiagnostic flakes of stone tool-making material were not formally recorded when they were single and isolated from the resources defined above by more than 100 meters. Ten of these single isolated flakes were identified in the project area. All were obsidian and all were located in the flat lakebed deposits between the lake edge embankment on the east and railroad tracks on the west. Several fragments of desiccated bone believed to be natural rather than cultural in origin were also observed on the flats. Although these materials were not subject to formal recording, their general locations are plotted on the cultural resource location map provided in Appendix C (Map 3).

The resource designated as 10-BT-1237 was originally recorded by archaeologists from ISU in 1985 as an isolated projectile point fragment (Reed et al. 1987). Investigations of this location and the nearby location of 10-BT-1236, another previously recorded isolate, in June of 2003 resulted in an expanded inventory of artifacts for each location. For 10-BT-1236, located inside the area of potential effects for the proposed landfill, a new site form was completed. Since site 10-BT-1237 remains outside of the area of potential effects, it was not re-recorded as part of this project. However, it is clear that the resource should be more fully investigated in any future land use decisions and should clearly be considered as an archaeological site rather than an isolated find. However, construction and operation of the new landfill will not impact this site.

Modern debris (scrap metal and nails, concrete chunks, sheet metal, misc. trash) probably associated with operations at the nearby TSF and IET facilities litters the surface of the ground throughout the proposed 64-acre landfill and especially in the southern portion. These materials were examined during the June 2003 surveys but were determined to be nondiagnostic and therefore of little use in understanding recent INEEL history. None of these materials were formally recorded. 


\subsection{Summary of Important Characteristics of Identified Resources}

Archaeological sites like those identified along the embankment in the TAN Landfill project area hold promise for understanding the ways in which Lake Terreton might have influenced prehistoric land use on the INEEL. Site 2003-22-3 (10-BT-1236) exhibits good integrity with little or no modern disturbance and may reflect use of the area during the most recent period of higher effective moisture and a documented highstand of the lake after 1000 years ago (Gianniny 2002). The Shoshone-Bannock Tribes also view all archaeological resources on the INEEL as important to their heritage and ongoing cultural traditions.

The integrity of site 2003-22-1 has been compromised by natural erosion of the embankment and by installation of a water line along the eastern perimeter of the site on top of the embankment. However, it is possible that undisturbed materials remain at the top of the embankment. This larger site may have also been occupied during the 1000-year-old period of lake expansion or it may be several thousand years older. The deposits currently preserved at the site probably contain datable hearths and/or cooking features that could help to delineate the temporal range of Elko Corner-notched points in the region while also informing about settlement and subsistence in the vicinity of Lake Terreton during the Middle Prehistoric period.

The single prehistoric Isolated Find documented in the project area (2003-22-2) and the ten isolated nondiagnostic flakes noted but not formally recorded provide additional confirmation of light use of the Lake Terreton vicinity. However, they are unlikely to yield any additional information of use in understanding the specific prehistoric activities conducted there. Larger sites, such as those located on the rim of the embankment (2003-22-1 and 2003-22-3/10-BT-1236), likely hold the key to understanding this unique and interesting physiographic zone on the INEEL.

\subsection{National Register Eligibility}

\begin{tabular}{|l|l|l|l|l|l|}
\hline Field No. & Site No. & Eligibility & Criteria & General Context & INEEL Context \\
\hline $2003-22-3$ & $10-$ BT-1236 & $\begin{array}{l}\text { Potentially } \\
\text { Eligible }\end{array}$ & "d" & Prehistoric Archaeology & $\begin{array}{l}\text { Prehistoric Native American: } \\
15,000-150 \text { BP }\end{array}$ \\
& & & Historic Native American & $\begin{array}{l}\text { Historic Native American: } 150 \\
\text { BP - present }\end{array}$ \\
\hline $2003-22-2$ & & Ineligible & N/A & N/A & N/A \\
\hline $2003-22-1$ & & $\begin{array}{l}\text { Potentially } \\
\text { Eligible }\end{array}$ & "d" & Prehistoric Archaeology & $\begin{array}{l}\text { Prehistoric Native American: } \\
15,000-150 \text { BP }\end{array}$ \\
& & & Historic Native American & $\begin{array}{l}\text { Historic Native American: } 150 \\
\text { BP - present }\end{array}$ \\
\hline
\end{tabular}

\subsection{Recommendations for Further Investigations}

The single Isolated Find (2003-22-2), ten isolated flakes in the flats below the embankment, and modern trash located in the TAN Landfill project area are unlikely to yield any additional information and are recommended as ineligible for the National Register as a result. The two archaeological sites recorded in the proposed landfill area (2003-22-1 and 2003-22-3/10-BT-1236) are evaluated as potentially eligible for nomination because they may contain information important in understanding prehistory. In order to fully evaluate the research potential of these two sites, archaeological test excavations must be completed 
to determine the depth and nature of any subsurface cultural deposits. Until these investigations are completed, the sites should be protected from adverse impacts.

\section{CONCLUSIONS AND RECOMMENDATIONS}

\subsection{Summary of Investigations}

Cultural resource investigations completed to determine if the proposed demolition landfill at TAN will have any effect on significant cultural resources included cultural resource archive searches, intensive archaeological field surveys, and coordination with the Shoshone-Bannock Tribes. In the area of potential effects for the project, three archaeological resources were formally recorded or re-recorded as a result of these efforts; two of the identified resources are potentially eligible for nomination to the National Register of Historic Places (2003-22-1, 2003-22-3/10-BT-1236) for their potential to yield information that may contribute to a better understanding of the past. These sites are also significant to the Shoshone-Bannock Tribes for their importance in tribal history and culture (Buckskin 2003). The third archaeological resource identified in the proposed Landfill project area is an isolated find location (2003-22-2) that is unlikely to yield any additional information and is ineligible for nomination to the National Register for its archaeological information potential. All three of the resources formally recorded as part of the landfill survey are located atop the steep embankment that marks the former edge of Pleistocene Lake Terreton.

In addition to these resources, ten single isolated flakes of stone tool material (obsidian) and a number of isolated surface finds of desiccated natural bone were also observed by the surveyors. All of these materials were widely scattered on flat lakebed deposits below the lake edge embankment. The flakes probably represent short-term transient cultural activities in the area and may be simple outliers to the more intensive activities represented at the larger archaeological sites nearby. The isolated bones are believed to be natural rather than cultural in origin. None of the locations where these materials were observed is likely to yield any additional information and as a result, all are considered ineligible for nomination to the National Register.

\subsection{Potential Threats to the Integrity of Identified Properties}

Ground disturbance within the new landfill at TAN will be intensive and ongoing. Heavy equipment will move routinely along the access road to the bottom of the embankment to drop off material from D\&D activities and to access stockpiled fill. Heavy equipment will also be used on top of the embankment to push fill on top of the D\&D material and to loosen materials to create stockpiles for later use. All of these activities could jeopardize the integrity of archaeological deposits present at the two sites located on top of the embankment. However, measures can be taken to prevent impacts to the identified resources.

In addition to direct impacts from heavy equipment and earth-moving, archaeological sites identified in the proposed landfill area could also be subject to indirect impacts as a result of higher visibility on the landscape and overall increases in activity levels throughout the life of the landfill. Artifacts may be subject to unauthorized collection as a result. Again however, additional measures can be taken to prevent these impacts.

\subsection{Relationship of Identified Properties to Project Impacts}

Map 4 in Appendix C shows the layout of the proposed TAN Demolition Landfill and access road in relation to the three archaeological resources identified during the surveys reported herein. Both of the National Register-eligible archaeological sites identified during the surveys are located in the area of potential effects. However, through a program of avoidance, monitoring, and worker education, the project can be completed with no adverse effects to these resources. 


\subsection{Avoidance or Mitigation Options}

The proposed TAN Landfill can be designed to avoid direct impacts to the two National Register eligible resources identified in the project area through the use of three basic strategies: avoidance, cultural resource monitoring, and worker education. Landfill cells can be designed around the locations of sites 2003-22-1 and 2003-22-3/10-BT-1236 and as an added measure of protection, fences can be constructed around sensitive deposits to prevent direct impacts. A program of cultural resource monitoring of sensitive areas adjacent to these fenced areas along the top of the embankment will help to ensure that any buried archaeological deposits encountered outside of the fences are handled appropriately. The significant sites can be protected from indirect impacts through a modest program of worker awareness and education. If these protective measures are implemented, the project can be completed with no adverse effects to the archaeological resources.

\subsection{Recommendations for Additional Investigations or Protection Measures}

In order to protect the two significant archaeological sites (2003-22-1, 2002-22-3/10-BT-1236) identified on top of the embankment from direct impacts, landfill operations will be designed specifically to avoid the site areas. Fences will be established around the perimeters of each resource to provide a barrier between the sensitive artifacts/deposits and landfill operations. Buffer zones along each fence will also be established and sloped in such a manner to prevent any accelerated erosion. Fences will be constructed of three strands of smooth wire and will display signs reading "Restricted Area." The TAN Landfill manager in coordination with the INEEL CRM Office will strictly control any access to the sites within the fences. When landfill operations are complete, a decade or more from now, the fences may be removed to allow the archaeological sites to blend more naturally with the surrounding landscape. However, any decisions to remove the fences will also be made in consultation with the INEEL CRM Office, who will in turn coordinate communications with the Shoshone-Bannock Tribes.

In recognition of the cultural sensitivity of the embankment and the possibility of encountering additional buried artifacts, cultural resource specialists will monitor heavy equipment operations on top of the embankment in the zone where ten outlying flakes related to Site 2003-22-1 and the single Isolated Find (2003-22-2) were identified. Monitoring may also be conducted in the vicinity of Site 2003-22-3/10-BT1236. Plans written to guide the operation of the Landfill will indicate alternative work locations within the 64-acre landfill in the event of a cultural resource discovery and will also include a set of simple procedures to be followed in the event that significant materials are encountered. The highly disturbed area adjacent to the TSF fence is a likely position for the alternative work area (Map 4, Appendix C).

Before ground-disturbing operations are initiated, outlying flakes associated with Site 2003-22-1 located along the top of the embankment will be systematically collected. The Shoshone-Bannock Tribes have specifically requested that these outliers to the main artifact concentration be relocated to a surface context within the fenced areas (Buckskin 2003). These intentional changes to the original spatial distribution of artifacts on the periphery of Site 2003-22-1 will be carefully documented and made part of the permanent site records. No diagnostic artifacts are included in the materials that will be relocated in this manner. Diagnostic artifacts designated as Isolated Find 2003-22-2 will also be systematically collected to prevent their disturbance by landfill operations.

Avoidance and protection measures as described above will make the sensitive archaeological sites more visible on the landscape and thus subject to possible indirect impacts. To avoid any adverse effects from this increased visibility, training will be provided for all individuals who work in or around the TAN Landfill to increase awareness of the archaeological and tribal sensitivities in the project area as well as legal obligations to protect cultural resources on the INEEL. 
The avoidance and protection measures described above will be detailed in Operations Plans prepared for the facility. If these measures are implemented, the project can be completed with no adverse effects to significant cultural resources.

\section{REPOSITORY}

Southeastern Idaho Regional Archaeological Center, Idaho Museum of Natural History, Idaho State University, Pocatello, Idaho. Records are also maintained and artifacts may be temporarily stored at the INEEL CRM Office, Bldg. IF-601, 2251 N. Blvd, Idaho Falls, Idaho.

\section{REFERENCES}

Arrowrock Group Inc., 1997, “The Idaho National Engineering and Environmental Laboratory: A Historical Context and Assessment, Narrative and Inventory," INEEL/EXT-97-01021, Boise, Idaho.

Braun, J. B., 2002, “INEEL Architectural Properties Management Plan,” INEEL/EXT-02-1338, Idaho Falls, Idaho

Bright, R. C. and O. K. Davis, 1982, "Quaternary Paleoecology of the Idaho National Engineering Laboratory, Snake River Plain, Idaho,” American Midland Naturalist 109:21-23.

Buckskin, L., 2003, Letter to B. Pace, July 8, 2003, on file at the INEEL CRM Office.

Gianniny, G. L., G. D. Thackray, D. S. Caufman, S. L. Forman, M. J. Sherbondy, and D. Findeisen, 2002, Late Quaternary Highstands in the Mud Lake and Big Lost Trough Subbasins of Lake Terreton, Idaho, in Link, P. K. and Mink, L. L., eds. "Geology, Hydrogeology, and Environmental Remediation: INEEL, Eastern Snake River Plain, Idaho," Geological Society of America Special Paper No. 353, p. 77-90, Boulder, CO.

DOE/ID, 2000, "Draft Idaho National Engineering and Environmental Laboratory Cultural Resource Management Plan," DOE/ID-10997, Rev 2., Idaho Falls, ID.

Holmer, R. N., S. R. Plager, B. R. Pace, and T. Grieve, 2002, “A GIS Predictive Model of Archaeological Sites in Eastern Idaho," Paper presented at the Great Basin Anthropological Conference, Elko, NV.

Idaho State Historic Preservation Office, 1995, Idaho Archaeological and Historical Survey Manual: Guidelines for Identifying and Evaluating Cultural Properties, Historic Preservation Series No. 8, Boise, ID.

Miller, S. J., 1984, A Cultural Resources Inventory of the Perimeter Boundary, Grazing Boundary, and 1984 Project Areas, Idaho National Engineering Laboratory, Southeastern Idaho. Document on file at the INEEL CRM Office, Idaho Falls, ID.

Nace, R. L., P. T. Voegeli, J. R. Jones, and D. Morris, 1975, “Generalized Geologic Framework of the National Reactor Testing Station, Idaho,” U. S. Geologic Survey Professional Paper No. 725-B, Washington, DC. 
Pace, 2000, "Cultural Resources Investigations for the Specific Manufacturing Capability Production Equipment Upgrade," INEEL/EXT-2000-01524, Idaho Falls, ID.

Reed, W. G., J. W. Ross, B. L. Ringe, and R. N. Holmer, 1987, "Archaeological Investigations on the Idaho National Engineering Laboratory: 1984-1985, Revised Edition," Swanson/Crabtree

Anthropological Research Laboratory Reports of Investigations: 87-1, Pocatello, ID. Document on file at the INEEL CRM Office, Idaho Falls, ID.

Ringe, B. L., 1995, Locational Analysis and Preliminary Predictive Model for Prehistoric Cultural Resources on the Idaho National Engineering Laboratory, MA thesis, Department of Anthropology, Idaho State University, Pocatello, ID.

Ringe, B. L., 1996, "Archaeological Survey and Test Excavation at Test Area North (TAN)," Internal Report No. LMIT-96-34, Idaho Falls, ID.

Ringe, B. L. and W. G. Reed, 1987, Archaeological Clearance of TAN Fire Station, TRA Drill Pad, RWMC Borehole, and Weapons Ranges Powerline, Letter Report to N. Stanley, EG\&G Idaho, Inc. June 15, 1987, Pocatello Idaho. Document on file at the INEL CRM Office, Idaho Falls, ID.

Ross, J. W., B. L. Ringe, and W. G. Reed, 1986, "Archaeological Surveys of Three INEL Gravel Pit Locations," Swanson/Crabtree Anthropological Research Laboratory Reports of Investigations No. 8512, Pocatello, ID. 


\section{APPENDIX A:}

\section{Key Information}
A. Project name:
TAN Demolition Landfill
B. Project number:
INEEL CRM $2003-22$
C. Agency name:
Bechtel BWXT Idaho, LLC, INEEL Cultural Resource Management Office for the Department of Energy Idaho Operations Office
D. Report author:
Brenda Ringe Pace
E. Principal Investigator: Brenda Ringe Pace
F. Report date:
June 2003
G. County:
Butte County

H. Legal locations:

\begin{tabular}{|l|l|l|}
\hline NAME OF AREA & LEGAL LOCATION & 7.5' MAP \\
\hline $\begin{array}{l}\text { TAN Demolition } \\
\text { Landfill }\end{array}$ & $\mathrm{S} 1 / 2$, Sec. 12, T6N, R31E & Circular Butte, Idaho 7.5 \\
& $\mathrm{N} 1 / 2$, Sec. 13, T6N, R31E & \\
\hline Access Road & $\mathrm{NE} 1 / 4$, Sec 13, T6N, R31E & Circular Butte, Idaho 7.5 \\
\hline
\end{tabular}

\section{Survey acreage:}

\begin{tabular}{|c|c|}
\hline $\begin{array}{l}65.75 \text { acres } \\
\text { Including: } 64 \text {-acre landfill and } 1.75 \text {-acre road }\end{array}$ & Intensive (20 meter interval) \\
\hline None & Reconnaissance (> 20 m interval) \\
\hline $\begin{array}{l}\text { Approximately } 1 \text { acre along TSF fenceline and } \\
<1 \text { acre in vicinity of IET } \\
\text { Note: these areas resurveyed because original } \\
\text { surveys were completed more than } 10 \text { years ago. }\end{array}$ & Previously surveyed (intensive) \\
\hline None & Previously surveyed (reconnaissance) \\
\hline
\end{tabular}




\section{APPENDIX B:}

\section{Certification of Results}

\section{CERTIFICATION OF RESULTS:}

I certify that this investigation was conducted and documented according to Secretary of Interior's Standards and Guidelines and that this report is complete and accurate to the best of my knowledge. 


\section{APPENDIX C: \\ Project Maps}

Appendix C contains a variety of maps. Some of them show the locations of cultural resources on the INEEL in the vicinity of the TAN Demolition Landfill. Only those resources located in proximity to or within the area of potential effects for this project are shown.

The locational information presented in these maps is distributed for Official Use Only and may have been removed from some versions of the document. It is exempted from the Freedom of Information Act under Section 9 of the Archaeological Resources Protection Act of 1979 (as amended) and under Section 304 of the National Historic Preservation Act of 1966 (as amended). Distribution of any cultural resource locational information from this document and particularly from this Appendix must be approved in advance by contacting the INEEL CRM Office, PO Box 1625-2105, Idaho Falls, ID 83415, telephone: (208) 526-0916.

The following maps are included here:

- a map showing the location of INEEL boundaries and major facilities (Map 1)

- a partial 7.5' topographic map (Circular Butte, Idaho) showing the area of potential effects for the proposed landfill and associated access road (Map 2)

- a partial 7.5' map (Circular Butte, Idaho) showing cultural resources within or near the area of potential effect for the proposed landfill and associated access road (Map 3)

- a plot plan of the proposed landfill illustrating the location of significant cultural resources in relation to operational features (Map 4) 
Map 1: General location of INEEL boundaries and major facilities.

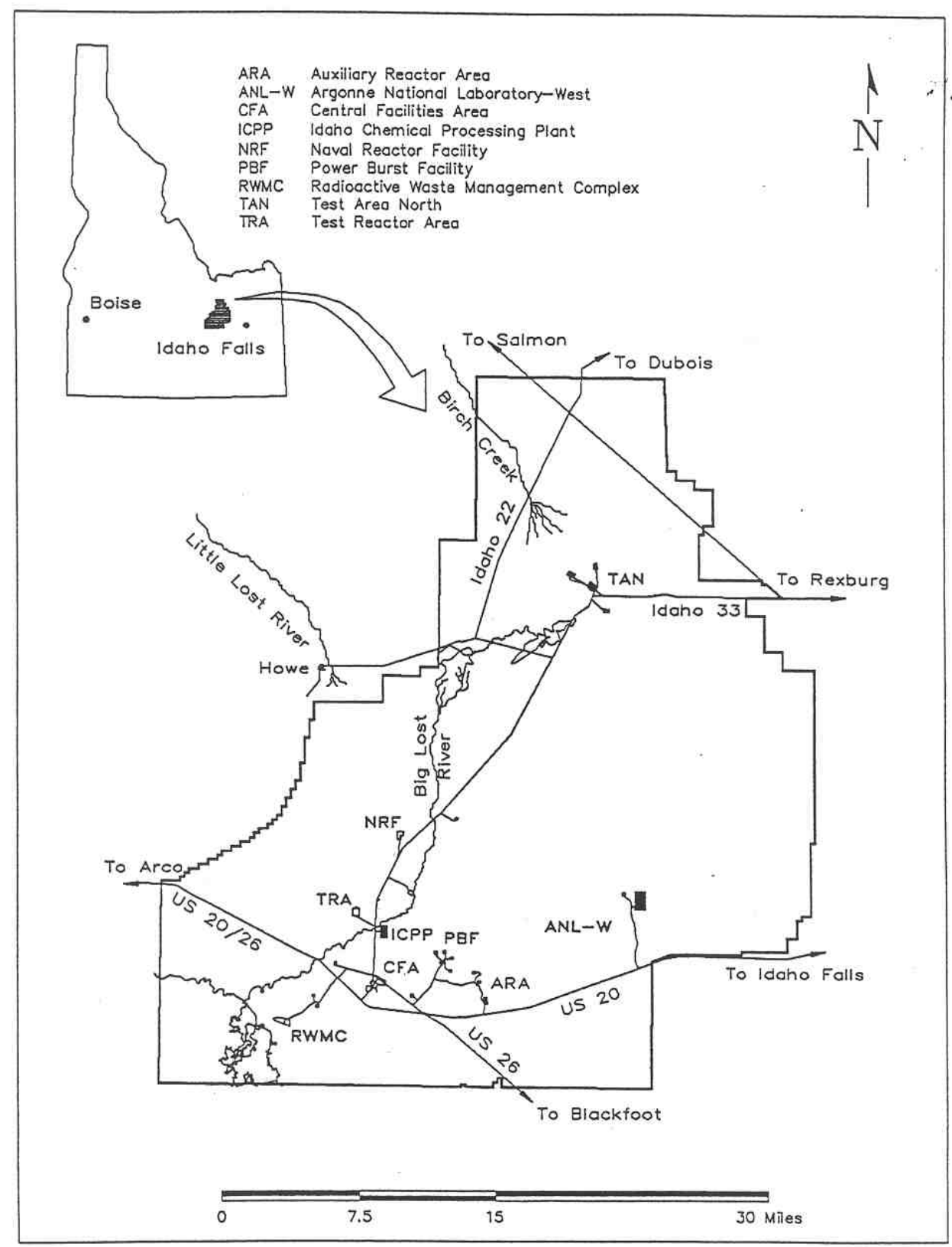


Map 2: partial 7.5' topographic map (Circular Butte, Idaho) showing the area of potential effects for the proposed landfill and associated access road.

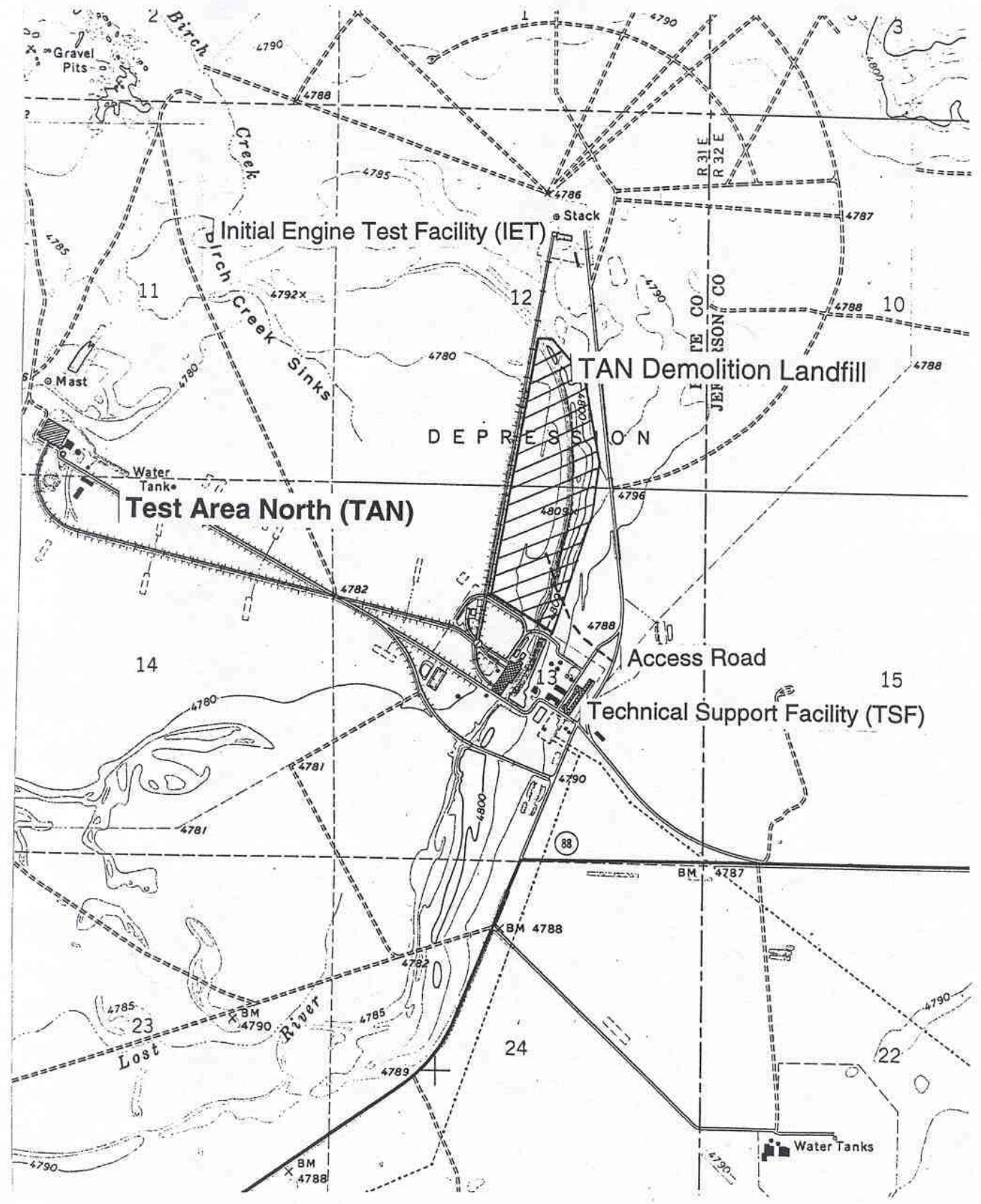




\section{APPENDIX D:}

\section{INEEL Site Recording Forms}

Appendix D contains field-recording forms for all of the cultural resources recorded in the area of potential effects for the proposed TAN Demolition Landfill. The locational information provided in this Appendix is distributed for Official Use Only and may have been removed from some versions of the document. It is exempted from the Freedom of Information Act under Section 9 of the Archaeological Resources Protection Act of 1979 (as amended) and under Section 304 of the National Historic Preservation Act of 1966 (as amended). Distribution of any cultural resource locational information from this document and particularly from this Appendix must be approved in advance by contacting the INEEL CRM Office, PO Box 1625-2105, Idaho Falls, ID 83415, telephone: (208) 526-0916. 